\title{
ERRATUM
}

\section{Good Enough To Eat}

\section{Friedemann Pfäfflin}

Published online: 4 March 2008

(C) Springer Science+Business Media, LLC 2008

Erratum to: Arch Sex Behav (2008) 37(2)

DOI 10.1007/s10508-007-9227-7

In this article, there were two errors in the Acknowledgments. The corrections are: (1) The paper was read at the international conference "Metamorphosen des Sinns: Unvernunft, Unsinn, Wahnsinn, Leichtsinn," held September 21-23, 2006, by the Latvian Academy of Culture and the Goethe-Institute of Riga,

Lithuania; (2) The author thanks the Latvian Academy of Culture and the Goethe-Institute of Riga for the permission to also publish the text in Archives of Sexual Behavior. The author regrets these errors.

The online version of the original article can be found under doi: 10.1007/s10508-007-9227-7.

F. Pfäfflin $(\bowtie)$

Forensic Psychotherapy, Ulm University, Am Hochsträss 8, 89081 Ulm, Germany

e-mail: friedemann.pfaefflin@uni-ulm.de 